九州大学学術情報リポジトリ

Kyushu University Institutional Repository

\title{
PLATYGASTRID PARASITES OF WILLOW GALL MIDGES IN JAPAN (HYMENOPTERA, PROCTOTRUPOIDEA)
}

Yamagishi, Kenzou

https://doi.org/10.5109/2407

出版情報: ESAKIA. 16, pp.161-175，1980-10-31. Entomological Laboratory，Faculty of Agriculture, Kyushu University バージョン :

権利関係 : 


\title{
PLATYGASTRID PARASITES OF WILLOW GALL MIDGES IN JAPAN (HYMENOPTERA, PROCTOTRUPOIDEA)*
}

\author{
KENZOU YAMAGISHI \\ Entomological Laboratory, Faculty of Agriculture \\ Kyushu University, Fukuoka 812, Japan
}

\begin{abstract}
Five new species of the family Platygastridae, Platygaster stimulator, P. riparia, P. urnicola, Synopeas yanagi and S. fuminale, which are parasitic on the willow gall midges, are described from Japan. Additionally, their host-parasite relationships and life-histories are discussed.
\end{abstract}

This is the first report of Japanese platygastrid wasps (Hymenoptera, Platygastridae) parasitic on the willow gall midges (Diptera, Cecidomyiidae), based on my studies conducted since 1975. Special attention has been paid to the midge genus Rhabdophaga, which makes various galls primarily on the salix species. Interesting informations on the host-parasite relationships, biologies of the platygastrid wasps and the larval characters of the latter were obtained.

The midge galls were collected from various willow species in April, June, August and October of 1975, mainly in Sapporo (Hokkaido), Morioka, Ojiya, Wakayama (Honshu), and Fukuoka (Kyushu) in respective seasons. The salix species were identified based primarily on the characters 'of their catkins and leaves, in collaboration with Mr. K. Senuma. Shortly after collecting of galls in April, many adults of platygastrid wasps and of gall midges emerged from these galls. No more insect emerged from these galls thereafter. Many larvae of host midges were taken out from the galls in summer and autumn, and they were dissected in the Ringer's solution to get the platygastrid larvae. When the latter was found out in the host larval bodies, they were immediately transferred using a glass micropipette to the Ringer's solution mixed with albumen on a hole slide, then they were examined under a microscope in order to clarify larval characters.

As a result, five species of the platygastrid wasps were reared from three

* Contribution from the Entomological Laboratory, Faculty of Agriculture, Kyushu University, Fukuoka (Ser. 3, No. 82). 
Table 1. The host-parasite relationships.

\begin{tabular}{l|l|l}
\hline Host plant of gall midge & \multicolumn{1}{c|}{ Host gall midge* } & \multicolumn{1}{c}{ Parasite } \\
Salix subfragilis Anders. & Rhabdophaga sp. & $\begin{array}{l}\text { Platygaster stimulator \& } \\
\text { P. riparia spp. nov. }\end{array}$ \\
Salix jessoensis Seem., etc. & Rhabdophaga salicivora Shin ji & $\begin{array}{l}\text { Platygaster urnicola } \text { sp. nov. } \\
\text { Salix spp. }\end{array}$ \\
\hline
\end{tabular}

species of the willow gall midges (Table 1). According to my study, these wasps are proved to be new species. The platygastrid larvae were confirmed only for three species of the genus Platygaster only. Unfortunately, the Iarva of two species of the genus Synopeas was not detected. Although, $P$. stimulator and $P$. riparia spp. nov. were bred from the same host midge, their life-histories are much different. For example, the former is in the first-instar larval stage in summer and in the pupal stage in autumn. On the contrary, the latter is in the embryonic stage in summer through autumn.

The holotypes of the new species described in this paper are deposited in the collection of the Entomological Laboratory, Kyushu University, Fukuoka, Japan.

Before going further I express my hearty thanks to Professor Y. Hirashima, Associate Professor K. Morimoto of Kyushu University, Fukuoka, and to Dr. L. Masner of Biosystematics Research Institute, Agriculture Canada, Ottawa, for their continuous encouragement and kind advice. I am much indebted to Professor G. Mineo of Universita degli studi di Palermo, Italy, for his kind advice on larval terminology, and to Associate Professor J. Yukawa of Kagoshima University, Kagoshima, for the identification of gall midges. I am also grateful to Mr. K. Senuma of Ojiya, Niigata Pref., for the identification and collecting of the willows, and to Mr. K. Setoya of Beppu, Ôita Pref., for the gift of materials.

\section{Platygaster stimulator sp. nov.}

(Figs. 1, 2, 11, 16, 21)

Female. Length $1.30-1.83 \mathrm{~mm}$ (on average of 90 specimens, $1.62 \pm 0.12$ $\mathrm{mm}$ ). Color: black; antenna black or blackish brown; all femora and tibiae almost blackish brown; apex of fore tibia and all tarsi brown; wings slightly darkened.

* According to Dr. J. Yukawa of Kagoshima University (personal communication), the generic and species names of these gall midges are under revised by Nijveldt and Yukawa (in preparation). 


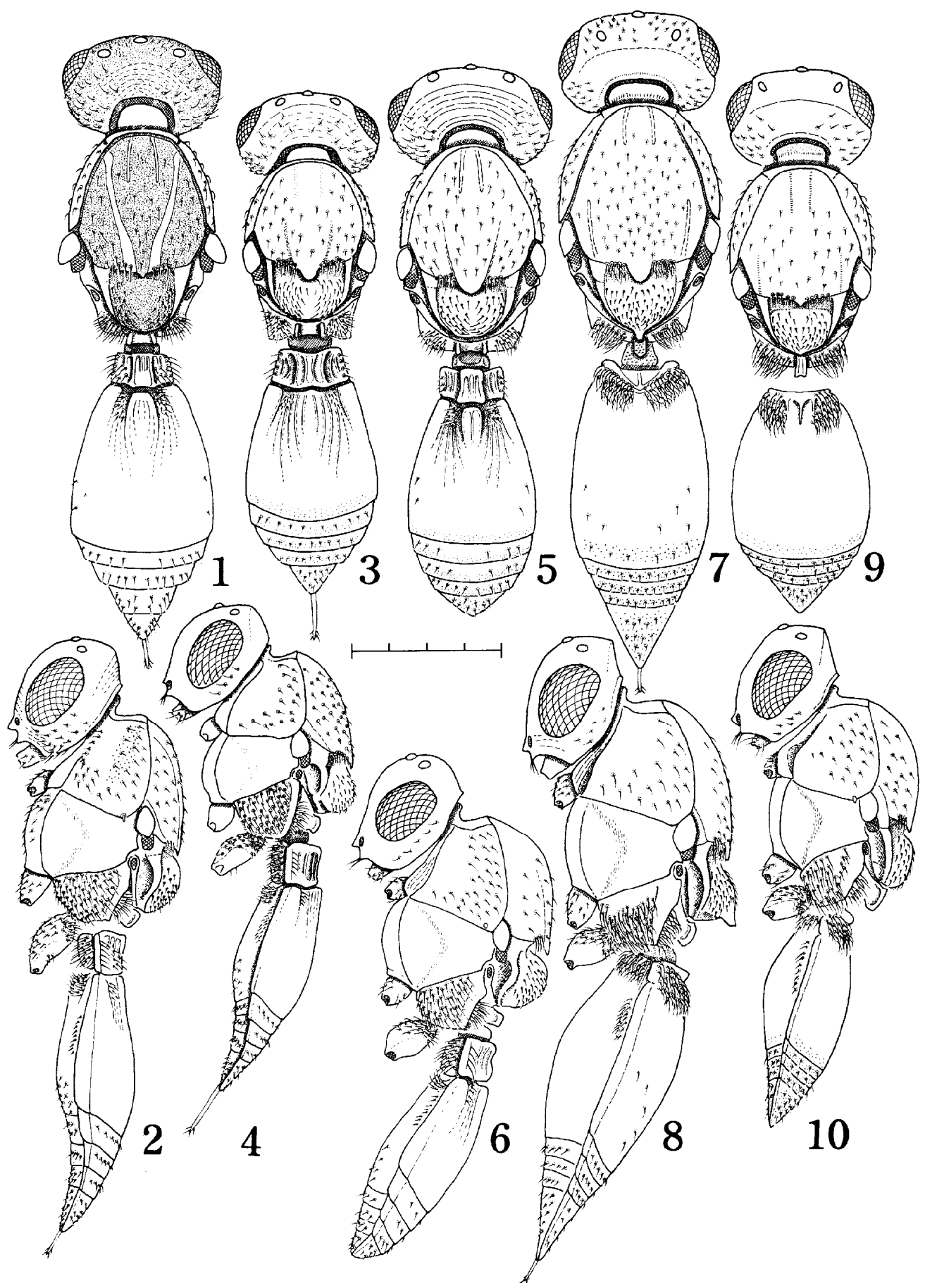

Figs. 1-10. Platygaster \& Synopeas spp. 1, 3, 5, 7, 9: Dorsal view. 2, 4, 6, 8, 10: Lateral view. 1, 2: $P$. stimulator sp. nov. 3, 4: P. riparia sp. nov. 5, 6: P. urnicola sp. nov. 7, 8: S. yanagi sp. nov. 9, 10: S. fuminale sp. nov. One scale : $0.1 \mathrm{~mm}$. 
Head transverse, $1.80 \mathbf{x}$ as broad as and $1.36 \mathbf{x}$ as high as long, slightly broader than thorax, $0.43 \times$ as long as thorax, reticulate coriaceous, sparsely covered with short hairs; occiput with several transverse weak striae, without hyperoccipital carina; POL shorter than $1 / 2$ of head width; OOL nearly $2 \times$ of diameter of lateral ocellus; eye $1.57 \times$ as high as long and $0.61 \times$ as high as head; gena $0.13 \times$ as high as head, with some weak transverse striae ; frons $0.63 \times$ as broad as head, rather smooth and shining, with some weak transverse striae around antennal sockets. Antenna (Fig. 11) $2.36 \times$ as long as height of head; relative length of each segment to whole antennal length, from scape to 10th segment, 33.6, 10.3, 4.0, 5. 9, 6.0, 6.2, 7.7, 7. 6, 7.6, 11.1 (on average of 5 specimens) ; ratio of width to length of each segment, 0.20, 0.46, 0.93, 0.77, 0.76, 0.79, 0.80, 0.85, 0.82, 0. 51 (on average of 5 specimens) ; scape $0.80 \times$ as long as height of head, slender, with weak longitudinal striae and sparse long setae of $15-30 \mu \mathrm{m}$; pedicel long ovoid, with some apical long stout setae; 3rd antennal segment subconical ; following segments rectangular, similar in shape, except oblong terminal 10th ; flagellum $1.67 \times$ as long as scape, densely covered with short setae of $5-25 \mu \mathrm{m}$; distal 6 segments each with some scattered stout setae of $15 \mu \mathrm{m}$; distal 4 segments forming a club and each segment with an apical short process of $10 \mu \mathrm{m}$.

Thorax, $0.47-0.67 \mathrm{~mm}$ in length (on average of 90 specimens, $0.56 \pm 0.05$ $\mathrm{mm}), 0.71 \times$ as broad as and $0.77 \times$ as high as long; anteromedian plate of pronotum glabrous; mesoscutum flattened, large, as long as width of thorax, almost reticulate coriaceous, smooth laterally, with sparse hairs ; parapsidal suture complete, shallow ; posterior margin of mesoscutum with a glabrous small process on median lobe and dense long hairs on lateral lobes; scutellum rather flattened, semicircular, reticulate coriaceous, with a pair of anterior foveae and sparse hairs; propodeum with a pair of longitudinal lamellae in middle and dense pubescence on side; lateral plate of pronotum slightly hairy, almost smooth, with a reticulate coriaceous portion centrally; propleuron narrow, faintly reticulate; mesopleuron glabrous; metapleuron densely pubescent. Legs slender, clavate, weakly reticulate, slightly hairy. Fore wing $0.40 \times$ as broad as long, $2.30 \times$ as long as thorax, considerably exceeding apex of abdomen when folded; hind wing $0.81 \times$ as long as fore wing, with 2 hamuli.

Abdomen flattened, elliptical, $0.55 \times$ as high as broad, $1.46 \times$ as long as thorax; 1st tergite short, transverse, $0.21 \times$ as long as 2nd tergite, smooth, slightly elevated in middle and depressed on side, with some longitudinal ridges medially and laterally and sparse hairs laterally; 2nd tergite large, $0.93 \times$ as broad as long, longer than $1 / 2$ of abdominal length, $0.80 \times$ as long as thorax, almost glabrous, with many longitudinal striae occurring from a pair of anterior hairy foveae ; these striae exceeding $1 / 3$ of the segment; following 3 tergites transverse, similar in shape; terminal tergite triangular; 


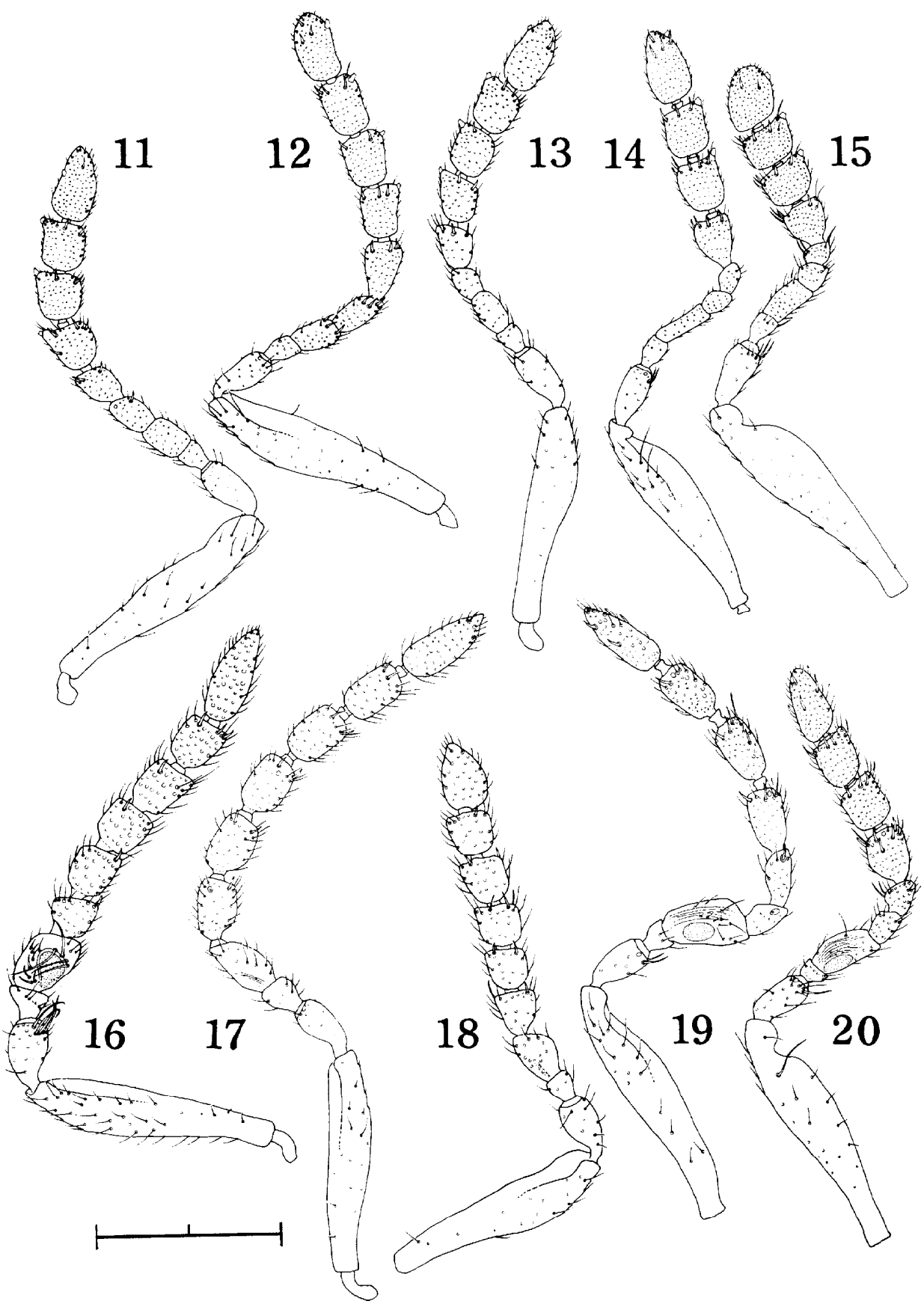

Figs. 1 1-20. Antennae of Platygaster \& Synopeas spp. 11-15: Female antennae. 16-20: Male antennae. 11, 16: P. stimulator sp. nov. 12, 17: P.riparia sp. nov. 13, 18: P. urnicola sp. nov. 14, 19: S. yanagi sp. nov. 15, 20: S. Aluminale sp. nov. One scale : $\mathbf{0 . 1} \mathbf{m m}$. 
these 4 tergites together $0.62 \times$ as long as 2 nd tergite, slightly hairy; 1 st sternite densely pubescent ; 2nd sternite almost glabrous, with a pair of anterior pubescent foveae and of lateral hairy furrows.

Male. Very similar to female except as follows : Length $1.14-\mathbf{1 . 6 8} \mathrm{m} \mathrm{m}$ (on average of 53 specimens, $1.48 \pm 0.11 \mathrm{~mm}$ ). Antenna (Fig. 16) $2.41 \mathrm{x}$ as long as height of head; relative length of each segment to whole antenna1 length, from scape to 10 th segment, 32.6, 9.1, 4.2, 8.2, 5.6, 6.6, 7.0, 7.1, $7.4,12.1$ (on average of 7 specimens) ; ratio of width to length of each segment, $0.20,0.57,1.21,0.87,0.95,0.85,0.86,0.86,0.81,0.46$ (on average of 7 specimens) ; scape $0.80 \times$ as long as height of head; pedicel ovoid, with some long hooked stout setae of $60 \mu \mathrm{m}$ apically; 3rd antenna1 segment subconical; 4th oblong, with a large ovoid sensorial plate of $38 \times 30 \mu \mathrm{m}$, some long curved setae of $60 \mu \mathrm{m}$ and some short stout setae of $15-18 \mu \mathrm{m}$; following segments rectangular, similar in shape, except long ovoid terminal segment; flagellum $1.79 \times$ as long as scape, sparsely covered with setae of $15-25 \mu \mathrm{m}$, distal 6 segments also with some scattered stout setae of $15 \mu \mathrm{m}$ respectively. Thorax $0.43-0.66 \mathrm{~mm}$ in length (on average of 53 specimens $0.58 \pm 0.04 \mathrm{~mm}$ ). Abdomen flattened, oval, $1 / 2$ as high as broad, 1.17 as long as thorax; 2nd tergite as broad as long, $0.73 \times$ as long as thorax; distal 5 tergites transverse, these together $1 / 2$ as long as 2nd tergite.

BIOLOGY : P. stimulator was reared from the rosette gall (Fig. 25) of Rhabdophaga sp. on the terminal bud of Salix subfragilis Anders. This species is a solitary parasite and appearing from late April to early May, with a single generation a year. Although the unparasitized host larva is young in summer and matures in winter, the parasitized host larva matures in summer, and the parasite pupates in autumn in the host larva. Thus, the larva of this wasp is considered to stimulate the development of host larva.

Description of larva : First-instar larva of P.stimulator (Fig. 21) small in size, 0. 13-0. $16 \mathrm{~mm}$ in length, slender and simple in shape, similar to the cyclopiform and to that of Platygaster herrickii Packard (Hill et Emery, 1937) ; cephalothorax membranous ; antenna membranous, slender, about $8 \mu \mathrm{m}$; mandible relatively large, chitinous, $25-35 \mu \mathrm{m}$, not dentate ; labium chitinous, trapezoidal, tetradentate ; abdomen membranous, without segmentation ; extreme tip of abdomen with a pair of membranous short stout caudal processes. This larva was usually found solitarily, floating freely in the haemocoele of host larva.

Distribution: Japan (Honshu).

Type MAterial: Holotype 우 (Type No. 2210, Kyushu Univ.), emerged on 27. iv. - 4. v. 1975, reared from the gall of Rhabdophaga sp. on Salix subfragilis Anders., the Shizukuishi River, Morioka, Honshu, 23. iv. 1975, K. Yamagishi leg. Paratypes : 99 우우, 48 ðる, em. on 27. iv.-4. v. 1975; 7 우우, 7 るð, em. on

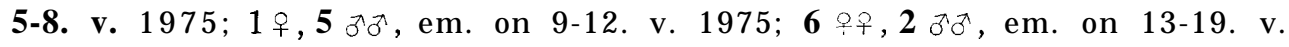




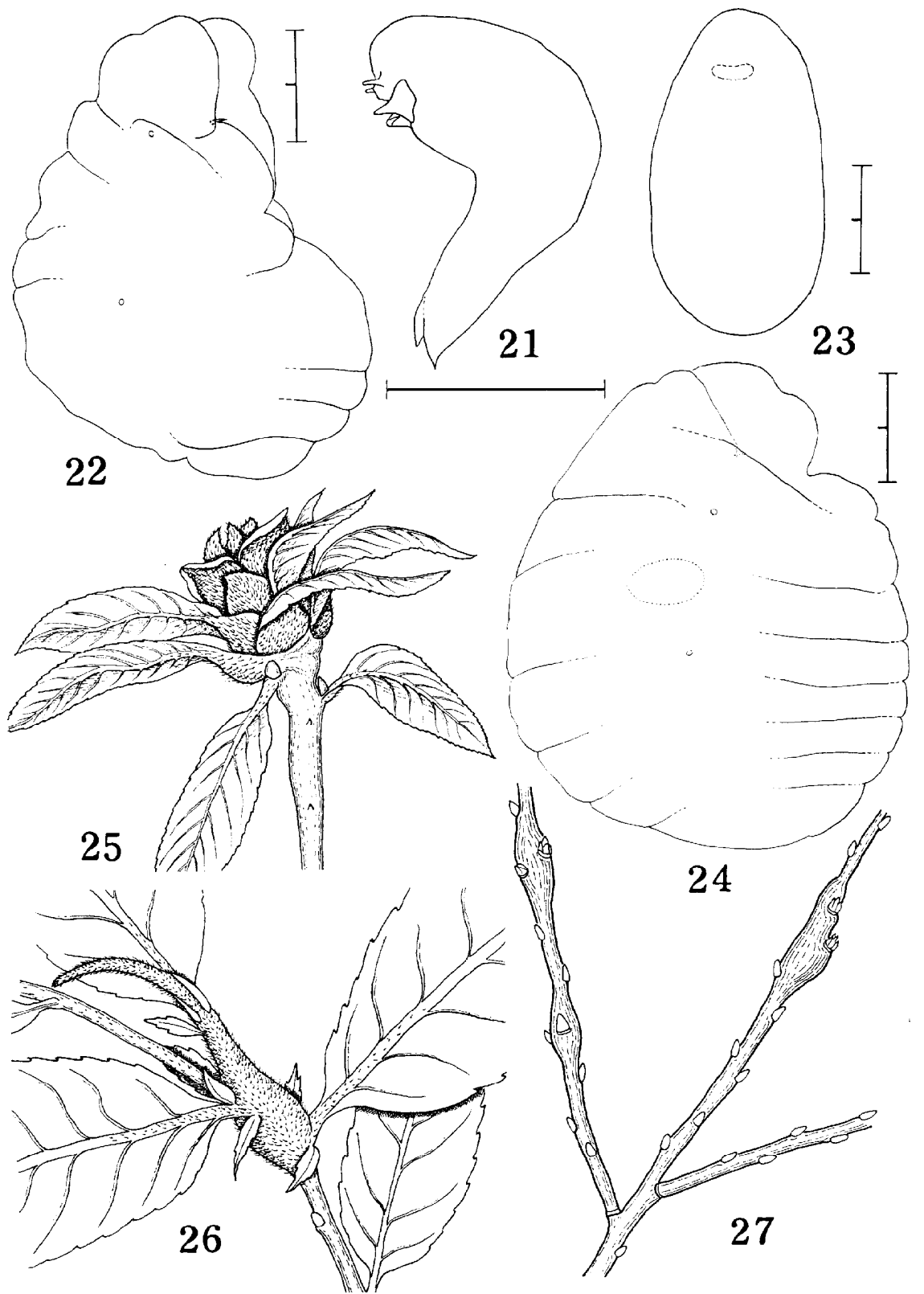

Figs. 21-24. Larvae of Platygaster spp. 21-23: First-instar larvae. 21: P. stimulator sp. nov. 22: $\mathbf{P}$. riparia $\mathrm{sp}$. nov. 23: $\mathbf{P}$. urnicola $\mathrm{sp}$. nov. 24: Mature larva of $\mathbf{P}$. urnicola sp. nov. One scale : $0.1 \mathrm{~mm}$. Figs. 25-27. Galls of willow gall midges. 25: Rosette gall of Rhabdophaga sp. on terminal bud of Salix subfragilis Anders. 26: Spindle-shaped gall of $\mathbf{R}$ habdophaga salicivora Shinji on twig of Salix jessoensis Seem. 27: Irregularly swollen galls of Rhabdophaga yanagi (Shinji) on twigs of Salix babylonica L. 
1975, same data as the holotype.

REMARKS: This species is different from any other Platygaster species associated with the willow gall-midges in having the complete parapsidal suture and the reticulate coriaceous sculpture on the head and thorax.

\section{Platygaster riparia sp. nov.}

(Figs. 3, 4, 12, 17, 22)

Female. Length $1.21-1.74 \mathrm{~mm}$ (on average of 50 specimens $1.46 \pm 0.14$ $\mathrm{mm}$ ). Color : black; middle and hind legs and fore femur blackish brown ; fore tibia and tarsus brown; wings hyaline.

Head transverse, $1.86 \times$ as broad as and $1.40 \times$ as high as long, slightly broader than thorax, $0.43 \mathrm{x}$ as long as thorax, almost glabrous and indistinctly reticulate coriaceous; occiput with several transverse weak striae along its margin, with a distinct hyperoccipital carina; POL $0.41 \times$ width of head; OOL more than $2 \mathrm{x}$ of diameter of lateral ocellus; eye $1.59 \times$ as high as long and $0.64 \mathrm{x}$ as high as head; gena $0.14 \times$ as high as head, with some weak transverse striae; frons $0.67 \times$ as broad as head, with some weak transverse striae around antennal sockets, and with a row of short hairs along eye margin. Antenna (Fig. 12) $2.47 \times$ as long as height of head; relative length of each segment to whole antennal length, from scape to 10th segment, 32.2, 9.3, $3.9,5.9,6.7,7.7,7.9,7.9,7.9,10.6$ (on average of 6 specimens) ; ratio of width to length of each segment, $0.23,0.50,0.85,0.68,0.58,0.62,0.72$, $0.74,0.72,0.50$ (on average of 6 specimens) ; scape slender, $0.80 \times$ as long as height of head, with weak longitudinal striae and sparse long setae of $15-30$ $\mu \mathrm{m}$; pedicel long ovoid; 3rd and 5th antennal segments subconical; 4th and 6th oblong; 7th to 9th rectangular; terminal segment long ovoid; flagellum $1.82 \times$ as long as scape, densely covered with short setae of $6-20 \mu \mathrm{m}$, distal 7 segments each with some scattered stout setae of $13 \mu \mathrm{m}$ apically ; distal 4 segments forming a club and each segment with an apical short process of $8 \mu \mathrm{m}$.

Thorax, $0.41-0.60 \mathrm{~mm}$ in length (on average of 50 specimens, $0.52 \pm 0.06$ $\mathrm{mm}), 0.73 \times$ as broad as and $0.81 \times$ as high as long; anteromedian plate of pronotum glabrous; mesoscutum large, slightly shorter than width of thorax, slightly hairy, almost smooth, weakly reticulated anteriorly, with a pair of weak parapsidal sutures on posterior half; posterior margin of mesoscutum with a glabrous semicircular lamella on median lobe and dense long hairs on lateral lobes; scutellum convex, semicircular, hairy, with a pair of foveae anteriorly; propodeum with a pair of longitudinal lamellae in middle and dense pubescence on side; lateral plate of pronotum slightly hairy, almost smooth, with a weakly reticulated portion centrally; propleuron narrow ; mesopleuron glabrous; metapleuron densely pubescent. Legs slender, clavate, slightly hairy. Fore wing $0.41 \mathrm{x}$ as broad as long, $2.09 \mathrm{x}$ as long as thorax, slightly 
exceeding apex of abdomen when folded; hind wing $0.84 \times$ as long as fore wing, with 2 hamuli.

Abdomen flattened, elliptical, $0.54 \times$ as high as broad, $1.45 \times$ as long as thorax; 1st tergite short, transverse, $0.27 \times$ as long as 2nd tergite, slightly elevated in middle and depressed on side, with some longitudinal ridges medially and laterally and sparse hairs laterally; 2nd tergite large, as broad as long, $0.72 \times$ as long as thorax, slightly more than $1 / 2$ of abdominal length, almost glabrous, with many longitudinal striae occurring from a pair of anterior hairy foveae, which exceeding $1 / 2$ of the segment, and with weakly punctured posterior narrow margin ; following 3 tergites transverse, similar in shape, each with a transverse row of hairs and weakly punctured posterior margin; terminal tergite triangular, with sparse hairs; distal 4 tergites together 0.53 as long as 2nd tergite; 1st sternite densely pubescent; 2nd sternite almost glabrous, with a pair of anterior pubescent foveae and of lateral hairy furrows.

Male. Very similar to female except as follows : Length $1.12-1.58 \mathrm{~mm}$ (on average of 50 specimens $1.34 \pm 0.14 \mathrm{~mm}$ ), Head relatively broader and higher than in female, $1.92 \times$ as broad as and $1.43 \times$ as high as long. Antenna (Fig. 17) $2.76 \times$ as long as height of head; relative length of each segment to whole antennal length, from scape to 10th segment, 28.1, 8.1, 4.4, 8.3, 8.1, 7.9, 7.7, 7.7, 7.8, 12.1 (on average of 6 specimens) ; ratio of width to length of each segment, $0.22,0.55,0.99,0.58,0.63,0.670 .70,0.69,0.70$, 0.42 (on average of 6 specimens) ; scape $0.78 \times$ as long as height of head; 4th antennal segment swollen, oblong, with a narrow sensorial plate of $26 \times 5 \mu \mathrm{m}$, and with some weak longitudinal striae; following segments oblong, similar in shape, except long oval terminal segment, each with some scattered apical stout setae of $15 \mu \mathrm{m}$; flagellum $2.28 \times$ as long as scape, sparsely covered with long setae of $20-30 \mu \mathrm{m}$. Thorax $0.43-0.64 \mathrm{~mm}$ in length (on average of 50 specimens $0.53 \pm 0.06 \mathrm{~mm}$ ), narrower than in female. Abdomen flattened oval, $0.57 \times$ as high as broad, $1.16 \times$ as long as thorax; 2nd tergite slightly longer than broad, $0.69 \times$ as long as thorax; distal 5 tergites transverse, these together shorter than $1 / 2$ of 2 nd tergite.

Biology: Similar to the former species, this species was also reared from the rosette gall (Fig. 25) of Rhabdophaga sp. on the terminal bud of Salix subfragilis Anders. This species is a gregarious parasite, 2 or 3 adults emerge from a single host larva. The adult appears from late April to early May, slightly later than in the former species, with a single generation a year. This wasp does not stimulate the development of host larva, and perhaps pupates in late winter or early next spring.

Description of larva : First-instar larva of $P$. riparia (Fig. 22) nearly sacciform, $0.8-1$. Omm in length ; mandible small, about $50 \mu \mathrm{m}$, not dentate; segmentation indistinct; 1st thoracic and 1st abdominal segments each with a 
pair of spiracles. Usually 2 or 3 larvae were found in a single host larva.

Distribution: Japan (Honshu).

Type material: Holotype of (Type No. 2211, Kyushu Univ.), emerged on 5 - 8. v. 1975, reared from Rhabdophaga sp. on Salix subfragilis Anders., the Shizukuishi River, Morioka, Honshu, 23. iv. 1975, K. Yamagishi leg. Paratypes:

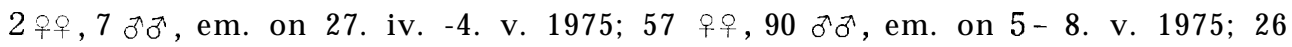

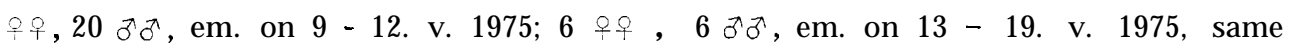
data as the holotype.

REMARKS: This species is similar to European Platygaster iteocrypta Kieffer, 1916, but is different in having the longer second tergite which is almost $2 x$ as long as the following segments together in female.

\section{Platygaster urnicola sp. nov.}

(Figs. 5, 6, 13, 18, 23, 24)

This species resembles the former species except as follows:

Female, Length $1.05-1.61 \mathrm{~mm}$ (on average of 87 specimens $1.33 \pm 0.11$ $\mathrm{mm}$ ). Color : black; antenna, all femora, and middle and hind tibiae blackish brown; fore tibia and all tarsi brown; wings hyaline.

Head 1.95 as broad as and 1.46 as high as long, $0.41 \times$ as long as thorax; head sculpture similar to that of the former species; hyperoccipital carina indistinct ; eye $1.56 \times$ as high as long, $0.56 \times$ as high as head; gena $0.18 \times$ as high as head. Antenna (Fig. 13) $2.31 \times$ as long as height of head; relative length of each segment to whole antennal length, from scape to 10th segment, 33.7, 9.7, 4.9, 6.4, 5.5, 6.6, 7.4, 7.4, 7.4, 11.2 (on average of 6 specimens) ; ratio of width to length of each segment, $0.21,0.50,0.72,0.74$ $0.86,0.78,0.89,0.87,0.84,0.54$ (on average of 6 specimens) ; basal antennal segments almost similar to those of the former species in shape ; distal 5 segments oblong, slightly shorter than those of the former species; flagellum $1.68 \times$ as long as scape ; each flagellar segment almost similar to that of the former species in structure.

Thorax $0.40-0.62 \mathrm{~mm}$ in length (on average of 87 specimens $0.51 \pm 0.05$ $\mathrm{mm}), \mathbf{0 . 7 1} \times$ as broad as and $0.80 \times$ as high as long; posteromedian process of mesoscutum smaller than in the former species. Fore wing $2.11 \times$ as long as thorax, moderately exceeding apex of abdomen when folded; hind wing $0.81 \times$ as long as fore wing, with 2 hamuli.

A bdomen $1.22 \times$ as long as thorax; 2 nd tergite more than $1 / 2$ of abdominal length, $0.67 \times$ as long as thorax, without punctured portion; longitudinal striae on 2 nd tergite exceeding $1 / 3$ of the segment; distal 4 tergites together $0.56 \times$ as long as 2 nd, smooth, slightly hairy, without punctured portion.

Male. Length $0.99-1.53 \mathrm{~mm}$ (on average of 70 specimens $1.25 \pm 0.12 \mathrm{~mm}$ ). Antenna (Fig. 18) $2.35 \times$ as long as height of head; relative length of each 
segment to whole antenna1 length, from scape to 10th segment, 32.8, 9.5, $4.6,8.5,6.4,6.4,6.6,6.9,6.8,11.7$ (on average of 6 specimens) ; ratio of width to length of each segment, $0.23,0.56,1.00,0.75,0.93,0.92,1.00,0.94$, $0.96,0.53$ (on average of 6 specimens) ; antenna 1 segments almost resemble those of the former species in structure; flagellum $1.77 \mathrm{x}$ as long as scape, sparsely covered with long setae of $15-25 \mu \mathrm{m}$; each of distal 6 segments similar in shape, almost quadrate. Thorax $0.38-0.61 \mathrm{~mm}$ in length (on average of 70 specimens $0.49 \pm 0.06 \mathrm{~mm}$ ), not narrower than in female. Abdomen $1.11 \mathrm{x}$ as long as thorax; 2nd tergite $0.64 \times$ as long as thorax.

Biology: . urnicola was reared from the gall (Fig. 26; subglobosity or spindle in shape, monothalamus) of Rhabdophaga salicivora Shinji on the apex of twig of Salix jessoemis Seem., S. eriocarpa Fr. et Sav., rarely of S. matsudana Koidz. cv. tortuosa Vilmorir, S. babylonica L. and ?S. koreensis Anders. This species is a gregarious parasite. Ten to thirty pupae of this wasp were found in a single host carcass, hence, this wasp probably exhibits the polyembryonic development. This species hibernates in the mature larval or pupal stage in the cocoons which are clustered in one host larval skin, and emerges from late April to early May, with a single generation a year.

Description of larva : First-instar larva of P.urnicola (Fig. 23) sacci-form, $0.60-0.65 \mathrm{~mm}$ in length, without mandible, spiracle nor segmentation. Mature larva (Fig. 24) nearly sacci-form, with a pair of mandibles of $50 \mu \mathrm{m}$, indistinct_ segmentation, and three pairs of spiracles on first, second thoracic and first abdominal segments.

Distribution: Japan (Honshu, Kyushu).

Type material: Holotype 우 (Type No. 2212, Kyushu Univ.), emerged on 28. iv. - 3. v. 1975, reared from Rhabdophaga salicivora Shinji on Salix jessoensis Seem., the Shinano River, Ojiya, Niigata Pref., Honshu, 27. iv. 1975, K. Yamagishi leg. Paratypes : 7 우우, em. on 28. iv.-3. v. 1975; 10 우우, 2 ðð, em. on 4-7. v. 1975, reared from R. salicivora on S. jessoensis, the Shizukuishi River, Morioka, Honshu, 23. iv. 1975. 59 우우, 9 ठ하, em. on 28. iv. - 3. v. 1975; 15 우우, $3 \delta^{3}$, em. on 4-7.v. 1975, reared from $R$. salicivora on S. jessoensis, the Tama River, Tazawako, Akita Pref., Honshu, 24. iv. 1975. 22 우우, 9 ðð, em. on 28. iv.

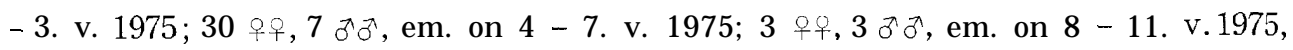
reared from $R$. salicivora on S. jessoensis, Kouma, Tamayama, Iwate Pref., Honshu, 25. iv. 1975. 87 우우, 26 § , em. on 28. iv. - 3. v. 1975, reared from $R$. salicivora on S. jessoensis, the Shinano River, Koshiji, Niigata Pref., Honshu, 20. iv. 1975. 165 우우, 36 ठðð, em. on 28. iv. - 3. v. 1975, reared from $R$. salicivora on $S$. jessoensis, Tsuchikawa, Ojiya, Niigata Pref., Honshu, 20. iv. 1975. 47 우, 6 \$6, em. on 28. iv. - 3. v. 1975, reared from R. salicivora on S. jessoensis, the Shinano River, Ojiya, Niigata Pref., Honshu, 21. iv. 1975. 30 우요 $11 \delta^{\dagger}$, same data as the holotype. 19 우, 3 ठ, em. on 28. iv. - 3. v. 1975, reared from R. salicivora on $\mathrm{S}$. matsudana cv. tortuosa, the Shinano River, Ojiya, Niigata Pref., Honshu, 21. iv. 
1975. All were collected by me.

Materials for reference: Many pupae, in galls of $R$. salicivora on S. eriocarpa Fr. et Sav., Inoseto, Beppu, Ôita Pref., Kyushu, 22. iii. 1975, K. Setoya leg. Many exuviae of pupa, same host and locality as above, 30. v. 1975, K. Yamagishi leg.

REMARKS: This species is similar to $\mathrm{N}$ orth American Platygaster feltii Fouts, 1920, which is also a gregarious parasite, but is different in having the broader head and the distinct club in the female.

\section{Synopeas yanagi sp. nov.}

(Figs. 7, 8, 14, 19)

Female. Length $1.50-1.83 \mathrm{~mm}$ (on average of 10 specimens $1.70 \pm 0.07$ $\mathrm{mm}$ ). Color: black; antenna, middle and hind legs blackish brown, fore leg brown ; wings hyaline.

Head transverse, $1.70 \times$ as broad as and $1.41 \times$ as high as long, slightly broader than thorax, $0.41 \mathrm{x}$ as long as thorax, reticulate coriaceous, with a weak hyperoccipital carina; POL nearly $1 / 2$ of head width; OOL 2 or $3 x$ diameter of lateral ocellus; eye $1.59 \mathrm{x}$ as high as long and $0.60 \mathrm{x}$ as high as head ; gena $0.16 \times$ as high as head ; frons $0.62 \times$ as broad as head, slightly hairy. Antenna (Fig. 14) $2.04 \times$ as long as height of head; relative length of each segment to whole antennal length, from scape to 10th segment, 34.7, 9.6, 4.9, 7.5, 4.3, 4.0, 7.7, 8.3, 8.0, 11.3 (on average of 6 specimens) ; ratio of width to length of each segment, $0.23,0.46,0.66,0.44,0.82,0.86,0.67$, $0.80,0.82,0.51$ (on average of 6 specimens) ; scape $0.71 \times$ as long as height of head, slender, weakly reticulate, with sparse long setae of $10-35 \mu \mathrm{m}$; pedi. cel long ovoid ;3rd, 5th to 7th antennal segments subconical; 4th long oblong; 8th and 9th quadrate; 10th oblong; flagellum $1.64 \times$ as long as scape, densely covered with short setae of $5-15 \mu \mathrm{m}$; 4-jointed club, each segment with some scattered stout setae of $7-15 \mu \mathrm{m}$ on apical margin and distal 3 segments also with an apical short process of $8 \mu \mathrm{m}$ respectively.

Thorax $0.58-0.65 \mathrm{~mm}$ in length (on average of 10 specimens 0.6110 .02 $\mathrm{mm}), 0.67 \times$ as broad as and $0.74 \times$ as high as long; anteromedian plate of pronotum glabrous ; mesoscutum convex, broad, as long as width of thorax, reticulate coriaceous, slightly hairy, without parapsidal suture ; posterior margin of mesoscutum with a glabrous small semicircular lamella medially, and dense hairs laterally; scutellum convex, densely covered with appressed short hairs, with a pair of foveae anteriorly; posterior spine of scutellum short, at most $2 x$ as long as broad, slightly upward; propodeum with a longitudinal lamella in middle and dense pubescence on side; lateral plate of pronotum reticulate coriaceous, slightly hairy ; propleuron narrow, weakly reticulate ; mesopleuron glabrous; metapleuron glabrous anteriorly, densely pubescent posteriorly. 
Legs slender, clavate, weakly reticulate, slightly hairy. Fore wing $0.38 \times$ as broad as long, $2.00 \times$ as long as thorax, slightly exceeding apex of abdomen when folded; hind wing $0.86 \times$ as long as fore wing, with 2 hamuli.

Abdomen spindle, $0.84 \times$ as high as broad, $1.39 \times$ as long as thorax; 1st tergite short, transverse, $0.15 \times$ as long as 2 nd tergite, almost fused to 2 nd tergite, densely pubescent laterally; 2nd tergite large, $0.77 \times$ as broad as long, longer than $1 / 2$ of abdominal length and $0.81 \times$ as long as thorax, almost glabrous, with a pair of pubescent anterolateral portions and weakly punctured posterior margin ; following 3 tergites transverse, similar in shape; terminal tergite triangular, slightly broader than long; distal 4 tergites together $0.60 \times$ as long as 2 nd tergite, almost weakly punctured, slightly hairy; 1st sternite densely pubescent; 2nd sternite almost glabrous, with a pair of hairy furrows anteriorly.

Male. Very similar to female except as follows : Length $1.50-1.67 \mathrm{~mm}$ (on average of 10 specimens $1.60 \pm 0.06 \mathrm{~mm}$ ). Antenna (Fig. 19) $2.32 \times$ as long as height of head; relative length of each segment to whole antennal length, from scape to 10th segment, 32.6, 8.0, 3. 5, 10.1, 4.2, 6.8, 8.0, 8.1, 7. 7, 11. 2 (on average of 6 specimens) ; ratio of width to length of each segment, 0.19 , $0.56,1.27,0.58,0.91,0.59,0.56,0.59,0.60,0.37$ (on average of 6 specimens) ; scape $0.76 \times$ as long as height of head, with sparse long setae of 10 $25 \mu \mathrm{m}$; pedicel ovoid; 3rd, 5th and 6th antennal segments subconical ; 4th oblong, with a ovoid sensorial plate of $35 \times 15 \mu \mathrm{m}$, and many longitudinal striae; 7th to 9th oblong, similar in shape; 10th long ovoid; flagellum $1.82 \times$ as long as scape, sparsely covered with setae of $10-25 \mu \mathrm{m}$; distal 4 segments each with some apical scattered stout setae of $15 \mu \mathrm{m}$. Abdomen oval, $0.73 \times$ as high as broad, $1.19 \times$ as long as thorax; 2nd tergite $0.83 \times$ as broad as long, $0.72 \times$ as long as thorax; distal 5 terpites transverse, similar in shape, together $0.45 \times$ as long as 2 nd tergite.

BIology: S. yanagi was reared from the gall (Fig. 27; irregularly swollen, polythalamus) of Rhabdophaga yanagi (Shinji) on the twig of Salix babvlonica L. and on ?S. eriocarpa Fr. et Sav. This species is probably a solitary parasite, appearing in late April, with a single generation a year.

Distribution : Japan (Kyus hu) .

TyPe material: Holotype of (Type No. 2213, Kyushu Univ.), emerged on 13. iv. - 5. v. 1975, reared from the gall of R habdophaga yanagi (Shinji) on Salix babylonica L., the Ruins of the Fukuoka Castle, Fukuoka, Kyushu, 10. iv. 1975, K. Yamagishi leg. Paratypes: 8 우우, 6 후, same data as the holotype. 1 우, $4 \precsim \jmath^{\circ}$, em. on 13. iv. - 5. v. 1975, reared from R. yanagi on ?S. eriocarpa, the Sue River, Higashi-ku, Fukuoka, Kyushu, 10. iv. 1975, K. Yamagishi leg.

Remarks: This species is similar to European Synopeas salicis Szelényi, 1940, but is different in having the longer OOL and the narrower second tergite. 


\section{Synopeas fluminale sp. nov.}

(Figs. 9, 10, 15, 20)

This species resembles the former species except as follows:

Female. Length $1.31-1.55 \mathrm{~mm}$ (on average of 8 specimens $1.46 \pm 0.08$ $\mathrm{mm}$ ). Color : black, except brownish fore femur and brown fore tibia and all tarsi; wings almost hyaline, slightly darkened.

Head $1.80 \mathrm{x}$ as broad as and $1.47 \mathrm{x}$ as high as long; hyperoccipital carina distinct; POL more than $1 / 2$ of head width; OOL nearly diameter of lateral ocellus; eye $1.65 \times$ as high as long, $0.67 \times$ as high as head; gena $0.12 \times$ as high as head; frons $0.55 \times$ as broad as head. Antenna (Fig. 15) $1.95 \times$ as long as height of head; relative length of each segment to whole antenna1 length, from scape to 10 th segment, 40.1, 11. 2, 4.2, 8.0, 3.8, 3.7, 6.3, 6.9, $6.6,9.2$ (on average of 6 specimens) ; ratio of width to length of each segment, $0.24,0.44,0.83,0.50,1.01,1.08,1.07,1.11,1.21,0.75$ (on average of 6 specimens) ; scape $0.78 \times$ as long as height of head, with sparse long setae of $10-50 \mu \mathrm{m}$; antennal segments almost resemble those of the former species in shape and structure except broader 4th segment and shorter club segments; flagellum $1.21 \times$ as long as scape.

Thorax 0.51-o. $61 \mathrm{~mm}$ in length (on average of 8 specimens $0.57 \pm 0.04$ $\mathrm{mm}$ ) ; posteromedian process of mesoscutum smaller than in the former species; scutellum rather flattened, subtriangular; posterior margin of scutellum ended in a vertical carina, instead of a distinct scutellar spine. Fore wing $0.41 \times$ as broad as long, $2.01 \times$ as long as thorax, moderately exceeding apex of abdomen when folded.

Abdomen $0.66 \times$ as high as broad, $1.15 \times$ as long as thorax; 2nd tergite $0.95 \times$ as broad as long, nearly $2 / 3$ of abdominal length, $0.69 \times$ as long as thorax; terminal tergite short, obtuse-angled triangular, $2 \times$ as broad as long.

Male. Length $1.30-1.54 \mathrm{~mm}$ (on average of 14 specimens $1.42 \pm 0.07 \mathrm{~mm}$ ). Color: black; antennal scape and basal flagellar segments brown or blackish brown; distal flagellar segments blackish brown; middle and hind femora and tibiae blackish brown; fore femur and tibia and all tarsi brown. Antenna (Fig. 20) $2.28 \times$ as long as height of head; relative length of each segment to whole antenna1 length, from scape to 10th segment, 36.4, 9.8, 3.0, 8.9, 4.4, $4.4,7.7,7.5,7.3,10.6$ (on average of 6 specimens) ; ratio of width to length of each segrnent, $0.21,0.50,1.13,0.54,0.79,0.84,0.73,0.78,0.81,0.47$ (on average of 6 specimens) ; scape $0.83 \times$ as long as height of head; ovoid sensorial plate of 4th segment $30 \times 20 \mu \mathrm{m}$; antennal segments almost resemble those of the former species in shape and structure ; flagellum $1.48 \times$ as long as scape, shorter than in former species. Abdomen $0.44 \times$ as high as broad, nearly as long as thorax ; 2nd tergite as broad as long, $0.65 \times$ as long as thorax; distal 5 tergites together $0.44 \sim$ as long as 2nd tergite. 
BIOLOGY: Similar to the former species, this species was also reared from the gall of Rhabdophaga yanagi (Shinji) (Fig. 27) on the twig of Salixbabylonica L. and of ?S. eriocarpa Fr. et Sav., and also reared from ?R. yanagi on Salix jessoensis Seem. This species is probably a solitary parasite, appearing from late April to early May, with a single generation a year.

Distribution: Japan (Honshu, Kyushu).

Type Material: Holotype \& (Type No. 2214, Kyushu Univ.), emerged on 13. iv. - 5. v. 1975, reared from the gall of Rhabdophaga yanagi on ?Salix eriocarpa, the Sue River, Higashi-ku, Fukuoka, Kyushu, 10. iv. 1975, K. Yama-

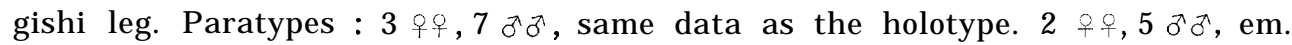
on 13. iv. - 5. v. 1975, reared from R. yanagi on S. babylonica, the Ruins of Fukuoka Castle, Fukuoka, Kyushu, 10. iv. 1975. 1 §, em. on $9-12$. v. 1975, reared from ? $R$. yanagi on S. jessoensis, the Shinano River, Ojiya, Niigata Pref., Honshu, 27. iv. 1975. 2 § $\delta^{7}$ em. on 8 - 11. v. 1975 and 1 우, em. on $12-19$. v. 1975, reared from ? R. yanagi on S. jessoensis, the Tama River, Tazawako, Akita Pref., Honshu, 24. iv. 1975. 18, em. on 12 - 19. v. 1975, reared from ?R. yanagi on S. jessoensis, Kouma, Tamayama, Iwate Pref., Honshu, 25. iv. 1975. All were collected by me.

REMARKS: This species is similar to European Synopeas neuroteri Kieffer, 1916, which also does not have the distinct scutellar spine, but is different in being larger and more blackish in color.

\section{References}

Ashmead, W. H., 1893. A monograph of the North American Proctotrypidae. Bull. U. S. Nat. Mus., 45: l-472.

Clausen, C. P., 1940. Entomophagous Insects, 688 pp.

Fouts, R. M., 1920. Some new parasites, with remarks on the genus Platygaster (Hym.). Proc.Ent.Soc. Wash., 22: 61-73.

- 1924. Revision of the North American wasps of the subfamily Platygasterinae. Proc. U. S. Nat. Mus., 63: 1-145.

- 1926. Notes on Serphoidea with descriptions of new species (Hym.). Proc. Ent. Soc. Wash., 28: 167-179.

Hill, C. C. et W. T. Emery, 1937. The biology of Platygaster herrickii, a parasite of the Hessian fly. Jour.Agr.Res., 55: 199-213.

Kieffer, J. J., 1913. Description de nouveaux Microhyménoptères.Brotéria, 11: 169-198.

— 1916. Beiträge zur Kenntnis der Platygasterinae und ihrer Lebensweise. Centr. Bakt. Paras.Infekt., 46: 547-592.

- 1926. Scelionidae. Das Tierreich, 48: 1-885.

Patterson, J. T., 1919. Polyembryony and sex. Jour. Heredity, 10: 344-352.

Szelényi, G., 1940. Ein Beitrag zur Kenntnis parasitischer Hymenopteren an Hand einiger Zuchtergebnisse. (Hymenoptera : Proctotrupoidea). Arb.morphol.taxon. Ent. BerlinDahem, 7: 226-236.

Yukawa, J., 1971. A revision of the Japanese gall midges (Diptera: Cecidomyiidae). Mem. Fac. Agr. Kagoshima Univ., $8:$ l-203. 